TEME, г. XLV, бр. 1, јануар - март 2021, стр. 231-246

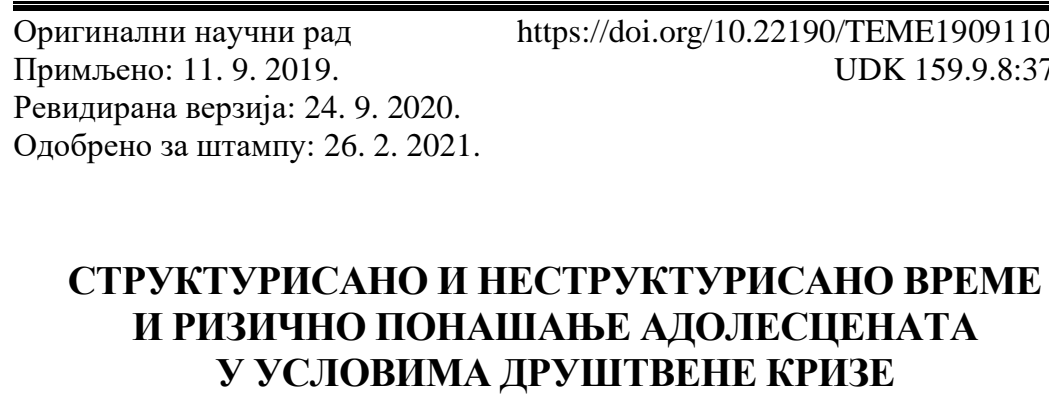

\author{
Биљана Јаредић", Јелена Минић, Татјана Радојевић \\ Универзитет у Приштини - Косовска Митровица, \\ Филозофски факултет, Косовска Митровица, Србија
}

\begin{abstract}
Апстракт
Циљ истраживања био је утврдити колико адолесценти радије бирају поједине типове структурисаног слободног времена и неструктурисаног времена (доколице), као и њихову повезаност са ризичним понашањем адолесцената у условима друштвене кризе. Узорак су чинили адолесценти $(\mathrm{H}=287), 116$ или 40,4\% мушких и 171 или 59,6\% женских испитаника, од 18 година до 24 године, просечне старости 20,44 године (AC $=20,44, \mathrm{CД}=2,75)$, који живе на територији Косова и Метохије. Коришћени су: Упитник за процену слободног времена и доколице (конструисан за потребе истраживања), Скала за процену ризичног понашања (енгл. Risk Behavior Rating Scale (RBRS); Scaar, 2009). Подаци су обрађени дескриптивном статистиком, корелационом и регресионом анализом, т-тестом. Резултати су показали да адолесценти најрадије бирају интернет као неструктурисану активност, а најмање позориште као структурисану активност. Добијена је негативна повезаност академског успеха и ризичног понашања, што указује на то да уколико адолесценти постижу боље резултате у академској каријери, имају мање склоности ка ризичном понашању. Према добијеним резултатима, младићи су склонији ризичном понашању од девојака, а ризично понашање адолесцената може се предвидети са $14 \%$ варијансе (значајни предиктори су неструктурисано слободно време и пол адолесцената). Један од циља рада био је да укажемо на значај структурисања слободног времена адолесцената у циљу подстицања њиховог адекватног раста и развоја, уз неопходно ангажовање стручњака из различитих области.
\end{abstract}

Кључне речи: слободно време, друштвена криза, ментално здравље, интервенције.

\footnotetext{
* Аутор за кореспонденцију: Биљана Јаредић, Филозофски факултет, Филипа Вишњића б.б. 38220 Косовска Митровица, Србија, biljkaja@gmail.com
} 


\title{
STRUCTURED AND UNSTRUCTURED TIME AND RISKY BEHAVIOR OF ADOLESCENTS IN CONDITIONS OF SOCIAL CRISIS
}

\begin{abstract}
The main objective of this research is to determine how much adolescents prefer certain types of structured free time and unstructured time (leisure time), as well as their connection with risky behavior of adolescents in social crisis. The sample consists of a number of adolescents $(\mathrm{N}=287), 116$ or $40.4 \%$ of male and 171 or $59.6 \%$ of female respondents, age from 18 to 24 , average age is 20.44 years ( $\mathrm{AS}=20.44$, $\mathrm{SD}=2.75$ ) living in the Autonomous Province of Kosovo and Metohija. Leisure and Leisure Assessment Questionnaire (constructed only for research purpose), Risk Behavior Rating Scale (RBRS), Scaar, 2009 were used in this research. The data was processed through descriptive statistics, correlation and regression analysis and the T-test. Results showed that adolescents mostly prefer internet as an unstructured activity and the least preferred is the theater as the structured one. A negative correlation was obtained between academic success and risky behavior, which indicates that if adolescents achieve better results in academic career, they have less propensity for risky behavior. According to the results, boys are more prone to risky behavior than girls, and risky behavior of adolescents can be predicted with $14 \%$ variance (significant predictors are unstructured leisure time and the gender of adolescents). Within our work, our objective is to bring attention to the importance of a structured way of spending leisure time regarding adolescents, with necessary engagement of experts from different areas.
\end{abstract}

Key words: leisure time, social crisis, mental health, intervention.

\section{УВОД}

Појмови слободно време и доколица често се користе као синоними, стварајући додатне проблеме истраживачима (Caldvell, 2008). Слободно време и доколица су комплексни и променљиви друштвени феномени (Cohen-Gewerc \& Stebbins, 2007), који су присутни у животу сваког појединца у различитим формама и детерминисани су културним и историјским околностима, узрастом, полом, занимањем, местом живљења, интересовањима итд. Стога се због бројних различитих, а неретко и супротстављених, значења (Henderson, 2010; Godbey, 2008), поред терминолошких дилема јављају и појмовне. Слободно време је време које особа проводи ван редовног, обавезног, позивног, домаћег или било каквог рада и извршавања задатака и служи за разоноду, одмор и рекреацију (Педагошки речник, 1967). Као саставни део живота сваког појединца и његове активности, слободно време се одређује и као време изван професионалних, породичних и друштвених обавеза, у којем појединац по својој вољи бира облике и садржаје одмора, разоноде и стваралаштва (Pedagoška enciklopedija, 1989).

Слободно време је предмет расправа од античких времена, па све до данас, али се као друштвени феномен проучава тек у индустријском друштву. Истраживањем слободног времена баве се 
стручњаци различитог профила: психолози, педагози, социолози, филозофи итд., отуда и бројне дефиниције и приступи истраживању. Различите перспективе гледања на слободно време рефлектују и разноликости у организацији и уређењу друштвеног живота и социјалних односа кроз историју и сврставају се у четири категорије, и то слободно време као: време, активност, стање духа и стање постојања (Goodbey, 2008) или као: преостало време, активност, функционално време и слобода (Rosić, 2005). У литератури се слободно време најчешће посматра као: време преостало од рада, ослобођено обавеза било које врсте, тежња за слободно изабраним (рекреативним) активностима и време проведено у активности која пружа интринзично награђујућа искуства (Csikszentmihaly \& LeFevre, 1989).

Када су у питању адолесценти, слободно време је, пре свега, педагошки проблем, простор самоактуализације и остварења личности, који омогућава интеракцију са другима неопходну у процесима индивидуализације, социјализације и инкултурације (Previšić, 2000). Са друге стране, и важан је чинилац развоја личности, који пружа могућност адолесцентима да активирају своје стваралачке снаге, задовоље интересе и потребе, као и социјално, емотивно, стручно, физичко, когнитивно ангажовање и развој (Irbi \& Tolman, 2002). Слободно време је простор за експресију аутентичног Ja (Holt, 1998), где не постоје баријере као у радном, образовном, друштвеном или породичном миљеу, у ком се адолесценти могу опустити и изразити свој прави идентитет, слободно бирајући активности (Irby \& Tolman, 2002). Прецизније, сматра се да је слободно време:

„важан фактор еманципације личности, услов за рекреацију и одмор, јер пружа могућност за социјализацију и хуманизацију личности и да је у функцији самовредновања и самоидентификације појединца" (Đorđević, 2003, p. 43).

Слободно време може се одредити и као укупност времена, стања и активности које нису условљене биолошком, социјалном и професионалном нужношћу, при чему је важно и да адолесценти преузму одговорност за сопствени развитак (Previšić, 2000).

У литератури постоји неслагање у вези са развојним могућностима и погодностима повезаним са структурисаним и неструктурисаним активностима адолесцената током слободног времена. Структурисане активности одликује јасна структура и учешће појединца које се одиграва унутар система који укључује ограничења, правила и циљеве (активности као што су: спорт, хоби, уметности, музика, учешће у волонтерском раду и слично) (Larson, 2000). У структурирању слободног времена наилазимо на садржаје који имају формативну (доприносе развоју здраве, културне и стваралачке личности), примарно-превентивну (отклањају негативне утицаје друштвено штетних поступака) и куративну улогу (средство преваспитања, по- 
себно у установама за рекреацију и ресоцијализацију) (Rosić, 2005). Насупрот томе, неструктурисано слободно време или доколица, дефинише се као време изван обавеза које се проводи без одређеног садржаја и поистовећује се са беспослицом, за разлику од структурисаног слободног времена, као термина са социолошком и педагошком конотацијом (Janković, 1973). Доколица се и у изворном значењу односи на слободно време (доконицу), док је доколичан онај који није заузет послом, који је беспослен или докон (Anić, 2009). Прецизније, доколица је „подручје свакодневног живота у којем појединац може реализовати неке од својих способности и интереса који у другим подручјима бивају занемарени" (Ilišin, 2002: 270). Неструктурисане активности обично подразумевају дружење са пријатељима, гледање телевизије и употребу телефона (Larson \& Verma, 1999), имају мало развојних бенефиција (Cooper, Valentine, Nye \& Lindsay, $1999)$ и носе са собом већи ризик од укључивања адолесцената у антисоцијална понашања (Mahoni, 2004; према Osgood, Wilson, O’Malley, Bachman \& Johnston, 1996).

Ризично понашање се углавном везује за адолесценте и као најчешћа ризична понашања наводе се: конзумирање цигарета, алкохола, дрога, често мењање сексуалних партнера, учествовање у крађама, агресивно понашање итд. Ризичним понашањима се сматрају сва она понашања којима особа доводи у опасност сопствено здравље и угрожава друштвене вредности (Ljubičić, 2012). Са аспекта развојних теорија, познато је да су деца и адолесценти често изложени различитим васпитним утицајима родитеља, вршњака и средине који нису у складу са хуманим циљевима њихове заштите и који могу изазвати различите облике ризичног понашања (Zloković i Vrcelj, 2010). Најчешћи етиолошки чинилац који се наводи у објашњавању ризичног понашања је непосредна средина у којој млади одрастају и живе (доступност наркотика, оружја, присутност насиља, миграције, економска криза, незапосленост, расна и/или етичка дискриминација). Значајан фактор за настајање ризичног понашања је и породична средина. Уколико су родитељи склони конзумацији наркотика, криминалу, превише попустљиви и слично, расте вероватноћа да ће се млада особа ангажовати у неком ризичном понашању (Ljubičić, 2012). Такође, као битни фактори који могу утицати на појаву ризичног понашања наводе се и ниско школско постигнуће, бежање из школе, дружење са вршњацима који имају проблеме у прилагођавању, затим бунт, социјална изолација, одређене личне карактеристике итд. (Bernstein \& Cassel, 2007, према Ljubičić, 2012).

Друштвена криза је сложен социолошки појам и дефинише се као илегитимност друштвеног система, у ком се доводи у питање постојећа структура система и угрожава његов идентитет, што доводи и до опште несигурности грађана који су кризом погођени (Vejnović, 
2004). Најчешће друштвена криза настаје у периодима када постојећа организација друштва и институције не обезбеђују задовољење човекових потреба, повољне услове за живот и рад (Munjiza, 2002) и не пружају могућност решавања постојећих проблема (Hafner, 1997). Друштвену кризу карактеришу: односи неусклађености, стагнације и противуречности у различитим социјалним сферама, с централном димензијом - политичком кризом (која се огледа у кризи институција власти и демократије) и нарушавањем нормалног функционисања и начина живота појединца и заједнице. Уколико је друштвена криза сложена и дуга, долази до промене односа појединца према животу, раду, другим људима, према самом себи, мењају се ставови и вредности, али и начини провођења слободног времена, као и однос према слободном времену (Ćurčić, 2005). Друштвена криза може имати последице по ментално здравље и опште психофизичко функционисање становништва свих узрасних група, нарочито деце и адолесцената, јер су они осетљивији на деловање стресора, њихове стресне реакције су интензивније и исходи неповољнији (Kaličanin i Petrović, 2001). Провођење слободног времена код адолесцената у условима друштвене кризе важно је за истраживање због тога што су с једне стране адолесценти осетљиви део популације, а с друге стране, одрастање у условима друштвене кризе доводи у питање и доступност ресурса за његово квалитетно и структурисано провођење. Због свега горенаведеног, циљна група овог истраживања су управо адолесценти. Такође, определили смо се да испитујемо провођење слободног времена код адолесцената, између осталог, и због тога што постоји пуно начина и могућности да се слободно време адолесцената структурише и учини квалитетнијим, што с друге стране може довести до бројних развојних бенефиција и позитивних ефеката на њихов развој и опште функционисање.

\section{МЕТОД}

Основни предмет истраживања био је испитати како адолесценти проводе, тј. структуришу, своје слободно време, и то структурисано и неструктурисано време, тј. слободно време и доколицу код адолесцената који живе у условима друштвене кризе, и њихову повезаност са ризичним понашањем. Основна идеја аутора рада била је да се добијени резултати искористе за стручно ангажовање, подршку и осмишљавање начина провођења слободног времена зарад заштите и унапређења менталног здравља адолесцената и могућих развојних бенефиција.

Циљ истраживања био је утврдити израженост појединих типова структурисаног и неструктурисаног слободног времена код адолесцената у условима друштвене кризе, као и њихову повезаност са ризичним понашањем. 
Задаци истраживања били су: утврдити израженост различитих типова слободног времена (структурисаног: бављење спортом и физичким активностима, певање и свирање, сценско-плесне активности (фолклор), хоби, позориште, читање књиге и волонтерски рад) и доколице (неструктурисаног: дружење са вршњацима, кафићи, играонице, Фејсбук, Твитер и остале друштвене мреже, шетња и лешкарење) и њихову временску димензију (колико времена проводе у датим активностима); утврдити разлике у изражености структурисаног и неструктурисаног слободног времена и ризичног понашања у односу на пол; утврдити повезаност структурисаног и неструктурисаног слободног времена са ризичним поншањем и неким социодемографским карактеристикама, као и предвидети ризично понашање адолесцената на основу варијабли које су укључене у истраживање.

У истраживање су укључене следеће варијабле: слободно време (структурисано и неструктурисано), ризично понашање и социодемографске варијабле (пол, године живота, успех у средњој школи, тј. на факултету, број чланова породице и редослед рођења). Коришћени су: Упитник основних социодемографских карактеристика (конструисан за потребе истраживања), Упитник за процену слободног времена и доколице и Скала за процену ризичног понашања (енгл. Risk Behaviour Rating Scale, скр. RBRS; Scaar, 2009).

Слободно време је:

„време које нам преостаје кад завршимо све своје радне, школске, породичне и друштвене обавезе и којим можемо располагати према своме нахођењу, без спољне присиле и принуде, како нам лично одговара и на начин који нам највише одговара" (Trnavac \& Đorđević, 2010, p. 126).

Варијабла слободно време операционализована је преко упитника који мери израженост одређене слободне активности и њену временску димензију. Упитник за коришћење слободног времена и доколице контруисан је након пилот-истраживања у којем су методом фокус-групе са младима издвојене различите врсте провођења слободног времена. У пилот-истраживању било је укупно 5 фокусгрупа, са 6 до 8 учесника, тј. адолесцената (од 15 година до 24 године). Основна питања у фокус-групама била су концентрисана око тога како изгледа њихова дневна рутина, где проводе време, са киме најчешће проводе време и како изгледа њихов један дан и слично. Прикупљени одговори фокус-групе даље су разврстани у одређене категорије, које су послужиле као значајна смерница за формулисање одговарајућих питања. Израженост одређене активности добијена је одговором на питање да ли млади упражњавају одређену активност (да, не), а временска димензија одређена је питањем колико времена проводе у датој активности на недељном нивоу.

Ризично понашање се дефинише као добровољно понашање које прати постојање одређеног објективног и/или субјективног сте- 
пена ризика (Стојадиновић, 2004, према Митровић, Смедеревац, Грујичић, \& Чоловић, 2006) и то су сва она понашања којима се доводе у опасност властито здравље и угрожавају друштвене вредности. Ова варијабла је операционализована помоћу Скале за процену ризичног понашања (Scaar, 2009), која се састоји из две супскале: понашање ризично по здравље и експлоративно понашање. У овом истраживању коришћена је само супскала понашања ризичног по здравље, која се састоји из 14 тврдњи. Коришћење само једне супскале из одређене скале није неуобичајено код истраживача, нарочито уколико је супскала добрих психометријских карактеристика. На нашем простору скраћену верзију ове скале, тј. супскалу ризичног понашања, користила је Станојевић (2019) у опсежном истраживању на узорку адолесцената. Притом је супскала ризичног понашања показала добре психометријске карактеристике. Испитаници се изјашњавају о свакој тврдњи на четворостепеној скали (1 - никад; 2 ретко; 3 - понекад и 4 - често). Скалом су обухваћена понашања попут ношења оружја, коришћења алкохола, коришћења марихуане, коришћења цигарета, упражњавања незаштићених сексуалних одноca, али и размишљање о самоубиству, лагање и варање. Укупан скор понашања ризичног по здравље добија се једноставним сабирањем скорова са свих ајтема и креће се од 14 до 56. Поузданост супскале је висока (Scaar, 2009), у овом истраживању износи 0,85 (Кронбах алфа коефицијент), што је исто као и у истраживању на узорку средњошколаца у Америци (Scaar, 2009). Социодемографске варијабле операционализоване су помоћу Упитника основних социодемографских карактеристика.

Узорак у истраживању су чинили испитаници, тј. адолесценти $(\mathrm{H}=287)$, оба пола, и то $116(40,4 \%)$ мушких и 171 женски испитаник (59,6\%), од 15 година до 24 године, просечне старости 20,44 (АС $=20,44$, СД $=2,75)$, који живе на територији Косова и Метохије. Адолесценција се одређује као процес биолошког и психосоцијалног сазревања, које се одвија у периоду од 10. до 24. године и дели се на рану (од 10. до 14. год.), средњу (од 15. до 19. год.) и касну (од 20. до 24. год.) адолесценцију. Подаци су обрађени у статистичком пакету SPSS 21 и притом су коришћене: дескриптивна статистика, корелациона и регресиона анализа, т-тест.

\section{РЕЗУЛТАТИ И ДИСКУСИЈА}

У Табели 1 и Табели 2 приказана је израженост различитих врста провођења слободног времена код адолесцената и временска димензија структурисаног и неструктурисаног времена. 
Табела 1. Израженост различитих врста провођења слободног времена код адолесиената

\begin{tabular}{|c|c|c|c|c|c|c|c|}
\hline Слободно време & & $\mathrm{f}$ & $\%$ & Слободно време & & $\mathrm{f}$ & $\%$ \\
\hline \multirow{2}{*}{ Вршњаци } & да & 263 & 91,6 & Интернет & да & 280 & 97,6 \\
\hline & не & 23 & 8,0 & & не & 7 & 2,4 \\
\hline \multirow[b]{2}{*}{ Спорт } & да & 178 & 62,5 & Позориште & да & 31 & 10,8 \\
\hline & $\mathrm{He}$ & 106 & 37,2 & & не & 256 & 89,2 \\
\hline \multirow{2}{*}{ Свирање/певање } & да & 114 & 40,0 & Читање књига & да & 234 & 82,1 \\
\hline & не & 171 & 60,0 & & $\mathrm{He}$ & 51 & 17,9 \\
\hline \multirow{2}{*}{ Фолклор } & да & 47 & 16,4 & Ленчарење & да & 251 & 87,5 \\
\hline & $\mathrm{He}$ & 239 & 83,6 & & $\mathrm{He}$ & 36 & 12,5 \\
\hline \multirow{2}{*}{ Хоби } & да & 188 & 65,7 & Гледање ТВ-а & да & 231 & 80,5 \\
\hline & $\mathrm{He}$ & 96 & 33,4 & & $\mathrm{He}$ & 56 & 19,5 \\
\hline \multirow{2}{*}{ Кафићи } & да & 264 & 92,0 & Шетња & да & 265 & 92,3 \\
\hline & не & 23 & 8,0 & & $\mathrm{He}$ & 22 & 7,7 \\
\hline \multirow{2}{*}{ Играонице } & Да & 88 & 30,7 & Волонтеризам & да & 45 & 15,7 \\
\hline & $\mathrm{He}$ & 199 & 69,3 & & $\mathrm{He}$ & 242 & 84,3 \\
\hline
\end{tabular}

У Табели 1 приказана је израженост различитих врста провођења слободног времена (структурисаног: бављење спортом и физичким активностима, певање и свирање, сценско-плесне активности (фолклор), хоби, позориште, читање књиге и волонтерски рад) и доколице (неструктурисаног: дружење са вршњацима, кафићи, играонице, Фејсбук, Твитер и остале друштвене мреже, шетња и лешкарење) код адолесцената. Добијени резултати показују да адолесценти најрадије бирају интернет $(97,6 \%)$ као неструктурисану, а најмање позориште $(10,8 \%)$ као структурисану активност.

Табела 2. Израженост временске димензије структурисаног и неструктурисаног времена

\begin{tabular}{|c|c|c|c|c|c|c|c|c|c|c|c|c|c|c|}
\hline Н. ниво & $\begin{array}{l}C \\
\phi\end{array}$ & $\begin{array}{l}C \\
\% \\
\end{array}$ & $\begin{array}{c}\Pi C \\
\Phi \\
\end{array}$ & $\begin{array}{c}\Pi C \\
\%\end{array}$ & $\begin{array}{l}\Phi \\
\phi\end{array}$ & $\begin{array}{l}\Phi \\
\%\end{array}$ & $\begin{array}{l}\Pi \\
\Phi \\
\end{array}$ & $\begin{array}{l}\Pi \\
\% \\
\end{array}$ & $\begin{array}{l}\Psi \\
\phi\end{array}$ & $\begin{array}{l}4 \\
\% \\
\end{array}$ & $\begin{array}{l}X \\
\phi\end{array}$ & $\begin{array}{l}X \\
\% \\
\end{array}$ & $\begin{array}{l}B \\
\Phi \\
\end{array}$ & $\begin{array}{l}B \\
\% \\
\end{array}$ \\
\hline$>$ од 1 ч. & 32 & 17,2 & 53 & 44,9 & 17 & 34,0 & 7 & 21,2 & 44 & 18,6 & 54 & 28,3 & 16 & 37,2 \\
\hline $1-5$ ч. & 86 & 46,2 & 29 & 24,6 & 20 & 40,0 & 22 & 66,7 & 121 & 51,3 & 86 & 45,0 & 15 & 34,9 \\
\hline 6-10 ч. & 51 & 27,4 & 16 & 13,6 & 4 & 8,0 & 3 & 9,1 & 53 & 22,5 & 34 & 17,8 & 6 & 14,0 \\
\hline < 10 ч. & 17 & 9,1 & 20 & 16,9 & 9 & 18,0 & 1 & 3,0 & 18 & 7,6 & 17 & 8,9 & 6 & 14,0 \\
\hline
\end{tabular}


Табела 3. Израженост временске димензије структурисаног и неструктурисаног времена

\begin{tabular}{|c|c|c|c|c|c|c|c|c|c|c|c|c|c|c|}
\hline & $B$ & $B$ & Иг. & Иг. & W & W & Ин. & Ин. & $\Pi$ & $\Pi$ & $T B$ & $T B$ & $\pi$ & $\pi$ \\
\hline Н. ниво & $\phi$ & $\%$ & $\Phi$ & $\%$ & $\phi$ & $\%$ & $\Phi$ & $\%$ & $\phi$ & $\%$ & $\phi$ & $\%$ & $\Phi$ & $\%$ \\
\hline$>1$ ч. & 30 & 11,2 & 34 & 38,6 & 54 & 20,0 & 25 & 8,9 & 46 & 17,3 & 44 & 19,2 & 44 & 17,5 \\
\hline $1-5$ ч. & 118 & 44,2 & 30 & 34,1 & 150 & 55,6 & 83 & 29,4 & 140 & 52,6 & 104 & 45,4 & 100 & 39,8 \\
\hline $6-10$ ч. & 60 & 22,5 & 14 & 15,9 & 41 & 15,2 & 80 & 28,4 & 55 & 20,7 & 49 & 21,4 & 66 & 26,3 \\
\hline < 10 ч. & 59 & 22,1 & 10 & 11,4 & 25 & 9,3 & 94 & 33,3 & 25 & 9,4 & 32 & 14,0 & 41 & 16,3 \\
\hline
\end{tabular}

Легенда: ф - фреквенција, \% - проценти; Н. ниво - недељни ниво; В - вршњаци; Иг. - играонице; Ш - шетња; Ин. - интернет; К - кафићи; ТВ - гледање ТВ-а; Л - ленчарење

У Табели 2 и Табели 3 приказана је израженост временске димензије структурисаног и неструктурисаног времена, тј. колико времена испитаници проводе у датим активностима на недељном нивоу (изражено у сатима). Добијени резултати показују да адолесценти у највећем проценту $(33,3 \%)$ више од 10 сати проводе на интернету, а само 3\% њих проводи у позоришту.

Када је у питању утврђивање разлика у изражености структурисаног и неструктурисаног слободног времена и ризичног понашања, резултати т-теста показали су да нема статистички значајних разлика у структурисаном и неструктурисаном времену у односу на пол (Табела 4).

Табела 4. Т-тест за варијабле структурисано и неструктурисано слободно време у односу на пол испитаника

\begin{tabular}{|c|c|c|c|c|c|c|c|}
\hline & \multicolumn{2}{|c|}{$\mathrm{AC}$} & \multicolumn{2}{|c|}{ СД } & \multirow[t]{2}{*}{$\mathrm{T}$} & \multirow[t]{2}{*}{ дф } & \multirow[t]{2}{*}{$\Pi$} \\
\hline & $\begin{array}{l}\text { Мушки } \\
\text { пол } \\
\end{array}$ & $\begin{array}{c}\text { Женски } \\
\text { пол }\end{array}$ & $\begin{array}{c}\text { Мушки } \\
\text { пол } \\
\end{array}$ & $\begin{array}{c}\text { Женски } \\
\text { пол }\end{array}$ & & & \\
\hline $\begin{array}{l}\text { Структурисано } \\
\text { слободно време }\end{array}$ & 2,91 & 2,72 & 1,36 & 1,29 & 0,875 & 274 & 0,383 \\
\hline $\begin{array}{l}\text { Неструктурисано } \\
\text { слободно време }\end{array}$ & 4,81 & 4,60 & 1,04 & 0,97 & 1,304 & 274 & 0,195 \\
\hline
\end{tabular}

Легенда: АС - аритметичка средина; СД - стандардна девијација; т - вредност т-статистика; дф - степен слободе и п - вероватноћа.

Статистички значајне разлике у ризичном понашању добијене су у односу на пол испитаника (Табела 5)

Табела 5. Т-тест за варијаблу ризично понашање у односу на пол

\begin{tabular}{|c|c|c|c|c|c|c|}
\hline & \multicolumn{2}{|c|}{$\overline{\mathrm{AC}}$} & \multicolumn{2}{|c|}{ СД } & \multirow[t]{2}{*}{$\mathrm{T}$} & дф \\
\hline & Мушки пол & Женски пол & Мушки пол & Женски пол & & \\
\hline $\begin{array}{l}\text { Ризично } \\
\text { понашање }\end{array}$ & 26,27 & 22,28 & 7,81 & 6,22 & 4,53 & 2740,001 \\
\hline
\end{tabular}

Легенда: АС - аритметичка средина; СД - стандардна девијација; т - вредност т-статистика; дф - степен слободе и п - вероватноћа. 
Приказани резултати показују да су испитаници мушког пола склонији ризичном понашању у односу на испитанице.

Резултати корелационе анализе показали су да постоји статистички значајна позитивна повезаност ризичног понашања и неструктурисаног времена код адолесцената ( $\mathrm{p}=0,257$; п < 0,01), док повезаност ризичног понашања и структурисаног времена у овом истраживању није статистички значајна. Резултати коралационе анализе даље показују да постоји статистички значајна негативна повезаност година живота испитаника са структурисаним ( $\mathrm{p}=-0,173$; п < 0,01$)$ и неструктурисаним временом ( $\mathrm{p}=-0,146 ; \Pi<0,05)$, али не и са ризичним понашањем. Подаци показују да постоји статистички значајна корелација ризичног понашања и школског успеха код средњошколаца обухваћених истраживањем. Наиме, гори школски успех указује на већи ризик од ризичног понашања код средњошколаца $(\mathrm{p}=-0,391 ;$ п < 0,01). Код испитаника који студирају није добијена статистички значајна корелација ризичног понашања и просечне оцене остварене на студијама. Нису добијене ни статистички значајне корелације ризичног понашања са бројем чланова породице и редоследом рођења испитаника.

Резултати регресионе анализе за ризично понашање адолесцената приказани су у Табели 6.

Табела. 6. Регресиона анализа за зависну варијаблу ризично понашање

\begin{tabular}{lccc}
\hline & \multicolumn{3}{c}{ Ризично понашање } \\
Предикатори & $P^{2}$ & $\Phi$ & $B$ \\
\hline Године & 0,14 & $14,96^{* * *}$ & \\
Пол & & & 0,10 \\
Неструктурисано & & $-0,25^{* * * *}$ \\
да: Бета стандардизовани регресиони коефицијенти; ${ }^{* *} n<0,01,{ }^{* * *} n$ &
\end{tabular}

Резултати регресионе анализе показују да се ризично понашање адолесцената може предвидети са $14 \%$ варијансе, при чему се најбоље предвиђање може остварити на основу пола и неструктурисаног времена. Године живота испитаника нису дале значајан допринос у овом моделу.

\section{ДИСКУСИЈА}

Резултати добијени у овом истраживању указују на то да адолесценти најрадије бирају интернет, затим кафиће, па следе шетња и „блејање” са вршњацима као неструктурисане активности и да притом у поменутим активностима проводе више од 10 сати недељно. Адолесценти најмање бирају позориште као структурисану активност, затим волонтеризам, па следи фолклор. Овај податак нам може указати на одређене ризике којима су адолесценти изложени, тј. раз- 
војне погодности које су им услед претежно неструктурисаног провођења слободног времена ускраћене. Наиме, резултати бројних истраживања показују да је учешће у структурисаним активностима повезано са повећаним задовољством везаним за школу (Gilman, 2001), већим академским достигнућем (Fredricks \& Eccles, 2006), смањеним ризиком од напуштања школе (Mahoney \& Cairns, 1997), нижом стопом депресије (Mahoney, Schveder \& Stattin, 2002). Затим, структурисане активности олакшавају психолошки раст и дозвољавају младима да буду активни у свом развоју (Larson, 2000) и истраживању сопственог иденититета (Fredricks, Alfeld-Liro, Hruda, Eccles \& Ryan,2002). C друге стране, резултати показују и да је време проведено у неструктурисаним активностима у позитивној корелацији са девијантним понашањима (учешће у криминалним активностима, опасна вожња, виши степен злоупотребе наркотика, конзумирање алкохола и слично) (Osgood, Wilson, O’Malley, Bachman \& Johnston, 1996) и лошим академским успехом (Cooper et al.,1999). Уопштено гледано, потенцијалне могућности добијене од слободног времена насупрот потенцијалним ризицима са којима се сусрећу приписују се ниском степену структуре унутар активности (Kleiber, 1999). Барнет je утврдио (Barnett, 2006) да је за младе људи који су изложени већој толеранцији на досаду и оне који су били у бољој могућности да се забављају користећи њихово окружење постојала већа могућност да се баве здравим активностима и фитнес-активностима. Са друге стране, спољашње активности биле су приоритетније за оне који су испољавали особине особа које жуде за узбуђењем (сензацијом) и оне који су вероватније били склони досади. Међу сличним редовимa, Iso-Ahola и Crowley (1991) у свом истраживању су пронашли везу између злоупотребе средстава зависности и досаде код младих.

У нашем истраживању се показало да структурисано време није значајно повезано са ризичним понашањем, што указује на то да се између структурисаног слободног времена и ризичног понашања умећу и неке друге варијабле, као што су особине личности, карактеристике менталног здравља депресивност и анксиозност, као и социјална подршка и други интерперсонални контексти које треба додатно испитати у наставку овог истраживања, али да је неструктурисано време значајно повезано и да је значајна предиктор ризичног понашања код младих.

Бројни радови говоре у прилог чињеници да су адолесценти мушког пола склонији делинквентном и агресивном понашању, конзумирању психоактивних супстанци, посебно алкохола и марихуане у односу на адолесценткиње (Buljan-Flander, Durman-Marijanović i Ćorić-Špoljar, 2007; Mihić i Bašić, 2008; Novak i Bašić, 2008; LebedinaManzoni, 2005, према Ricijaš, Krajcer i Bouillet, 2010.). Истраживања ризичног и делинквентног понашања адолесцената углавном показују значајне и конзистентне разлике у манифестацији те врсте понашања код дечака и девојчица. Код адолесцената се девијантно пона- 
шање чешће манифестује кроз насилност, док су код девојчица чешћи ненасилни облици понашања (крађа, превара, проституција и друго) (Leadbeater, Kuperminc, Blatti \& Hertzog, 1999, према Rizvan, 2013). Испитивање које је спроведено на узорку од 706 ученика виших разреда основних и средњих школа у Републици Хрватској показало је да су младићи статистички значајно склонији већини делинквентних понашања и ризичним, ненормативним понашањима од девојака. Међутим, резултати истог истраживања нису показали да постоје статистички значајне полне разлике код ризичних сексуалних понашања (Ručević, 2009, према Rizvan, 2013). Резултати добијени у овом истраживању потврђују претходнонаведено.

\section{ЗАКЉУЧАК}

На основу добијених резултата и њиховог сагледавања у односу на друга истраживања из ове области, може се закључити да адолесценти на простору Косова и Метохије проводе углавном неструктуисано слободно време (доколицу) и да време проведено у овим видовима активности утиче на ризично понашање адолесцената. Имајући у виду да је адолесценција развојни период повећаног ризика за криминална и ризична понашања, те појаву различитих психопатолошких симптома (Stanojević, Radović \& Jaredić, 2013; Videnović \& Baucal, 2011), радом настојимо да скренемо пажњу на значај структурисања слободног времена адолесцената у циљу подстицања адекватног раста и развоја, уз неопходно ангажовање стручњака из различитих области, пре свих психолога и педагога. Код нас слободно време и даље се сматра временом за одмор од свакодневних обавеза, па самим тим није ни структурисано. У неким развијеним земљама, формира се цела мрежа педагошких делатности које су усмерене на решавање важних питања које поставља слободно време. У Шведској, на пример, издваја се око милион круна (12 милиона динара) за организовање слободног времена, за оснивање педагошких катедри чија би област била слободно време. Боље разумевање димензије слободног времена доприносе квалитету живота (појединаца, заједница и квалитету животу у непосредном социјалним окружењу), па је вероватније да ћемо се више ценити и вредновати, а самим тим и квалитетније користити слободно време (Henderson, 2010). Узевши у обзир резултате истраживања, како страних тако и домаћих истраживача, те резултате добијене у овом истраживању, можемо тврдити да је слободно време потребно посматрати као један од кључних контекста за учење, здравље младих људи, те простор за њихово самоостварење и партиципацију. Такође, треба осмислити начин да, иако користе један начин упражњавања слободног времена (нпр. интернет), тај начин користе за структурисане активности и учење, а не за играње игрица и друштвене мреже. Такође, и кафићи могу нудити другачије садржаје, као што су нпр. културни кутак у оквиру кафеа који могу младима омо- 
гућити разне садржаје и омогућити развој њихових интересовања. Нарочито је важно структурисати слободно време адолесцената у условима друштвене кризе, неповољне промене и услови у средини могу да интензивирају и промене уобичајене облике психопатологије или допринесу појави нових облика психопатологије или поремећаја понашања (Ćurčić, 2005). Исходи адолесценције, као кризног развојног периода, зависе од личне историје адолесцената, капацитета њиховог психичког апарата (Mladenović \& Todorović, 2008), али и од услова у средини која их окружује (Minić, 2014). На струци је, али и на онима који су одговорни за одрастање младих родитеља и наставника, да осмисле структуру за уобичајене начине доколице и да то понуде младима за њихов што квалитетнији раст и развој.

Захвалница: Рад је резултат истраживања у оквиру пројекта ИИИ 47023 Косово и Метохија између националног идентитета и евроинтеграција, који финансира Министарство просвете, науке и технолошког развоја Републике Србије.

\section{ЛИТЕРАТУРА}

Anić, V. (2009). Veliki rječnik hrvatskoga jezika [The big Dictionary of Croatian language]. Zagreb: Novi liber.

Barnett, L. A. (2006). Accounting for leisure preferences from within: The relative contributions of gender, race or ethnicity, personality, affective style, and motivational orientation. Journal of Leisure Research (38), 445-474.

Buljan-Flander, G., Durman-Marijanović, Z., \& Ćorić-Špoljar, R. (2007): Pojava nasilja među djecom s obzirom na spol, dob i prihvaćenost/odbačenost u školi [The appearance of violence among the children in regards to gender, age and acceptance/rejection in the school]. Društvena istraživanja, 16 (1-2), 157-174.

Videnović, M., \& Baucal, A. (2011). Adolescenti i rizična ponašanja: odraz iracionalnosti ili racionalnosti [Adolescents and risky behavior: irrationality or rationality]. Psihološka istraživanja, XIV (1). 25-46.

Vejnović, D. (2004). Teorija tranzicije i društvena kriza [Theory of transition and society crisis]. Sociološki pregled, XXXVIII (1-2), 37-44.

Gilman, R. (2001). The relationship between life satisfaction, social interest, and frequency of extracurricular activities among adolescent students. Journal of Youth and Adolescence, 30, 749-767.

Godbey, G. (2008). Leisure in your life. New perspectives. State College, PA Venture Publishing.

Đorđević D. (2003). Pedagoški smisao slobodnog vremena [Pedagogical sense of leisure time]. Pedagogija, Beograd: Pedagoško društvo Srbije.

Zloković, J., \& Vrcelj, S. (2010). Rizična ponašanja djece i mladih [Risky behaviors among children and adults]. Odgojne znanosti, 12 (1), 197-213.

Ilišin, V. (2002). Interesi i slobodno vrijeme mladih [Interests and leisure time of the youngsters]. U Ilišin, V. I Radin, F.(ur.). Mladi uoči trećeg milenija (pp. 269302). Zagreb: Institut za društvena istraživanja - Državni zavod za zaštitu obitelji, materinstva i mladeži.

Irby, M., \& Tolman, J. (2002). Rethinking leisure time: Expanding opportunities for young people and communities (Tech. Rep.). Washington, DC: The Forum for Youth. 
Iso-Ahola, S. E., \& Crowley, E. D. (1991). Adolescent substance abuse and leisure boredom [Zloupotreba supstanci od strane mladih i dosada u slobodno vreme]. Journal of Leisure Research, 23, 260-271.

Janković, V. (1973). Slobodno vrijeme u suvremenoj pedagoškoj teoriji i praksi [Leisure time in modern pedagogical theory and practice]. Zagreb: Pedagoško-književni zbor.

Kleiber, D. A. (1999). Leisure experience and human development: A dialectical interpretation. New York: Basic Books.

Kaličanin, P., \& Petrović, D. (2001). Priručnik o stresu [Manual about stress]. Beograd: Institut za mentalno zdravlje.

Larson, R. W. (2000). Toward a psychology of positive youth development. American Psychologist, 55, 170-183.

Larson, R. W., \& Verma, S. (1999). How children and adolescents spend their time across the world: Work, play, and developmental opportunities. Psychological Bulletin, 125, 701-736.

Ljubičić, M. (2012). Pregled definicija i trendova rizičnih ponašanja mladih [Overview of definitions and risky behavior trends among the young]. Teme, 36(1), 85-100.

Mahoney, J. L., \& Cairns, R. B. (1997). Do extracurricular activities protect against early school dropout? Developmental Psychology, 33, 241-253.

Mahoney, J. L., Schweder, A. E., \& Stattin, H. (2002). Structured after-school activities as a moderator of depressed mood for adolescents with detached relations to their parenst. Journal of Community Psychology, 30, 69-86.

Mihić, J., \& Bašić, J. (2008): Preventivne strategije - eksternalizirani poremećaji u ponašanju i rizična ponašanja djece i mladih [Preventive strategies-external behavioural disorders and risky behavior among children and youngsters]. Ljetopis socijalnog rada, 15, 445-471.

Minić, J. (2014). Osećaj porodične koherentnosti kod adolescenata. [The Sense of family coherence among the adolescents]. Univerzitet u Nišu, Filozofski fakultet. Doktorska disertacija.

Митровић, Д., Смедеревац, С., Грујичић, С., \& Чоловић, П. (2006). Типолошки приступ ризичном понашању адолесцената [Typological approach to risky behavior among the adolescents]. Зборник Института за педагошка истраживања, 1, 264-278.

Mladenović, J., \& Todorović, J. (2008). Porodični činioci depresivnosti mladih [Family factors of depression among the young]. U Zborniku radova: Mladi $i$ porodica (pp. 63-76). Niš: Filozofski fakultet Niš, Departman za psihologiju, Centar za psihološka istraživanja.

Munjiza, M. (2002). Psihosocijalne posledice psihijatrijskih poremećaja [Psycho-social consequences of psychiatric disorders]. U Kaličanin, P. (Ur). Psihijatrija: zaštita mentalnog zdravlja, (pp. 279-319). Beograd: Medicinski fakultet.

Novak, M. \& Bašić, J. (2008). Internalizirani problemi kod djece i adolescenata: obilježja i mogućnosti prevencije [Internalized problems among children and adolescents: features and chances for prevention]. Ljetopis socijalnog rada, 15 (3), 473-498.

Osgood, D. W., Wilson, J. K., O’Malley, P. M., Bachman, J. G., \& Johnston, L. D. (1996). Routine activities and individual deviant behavior. American Sociological Review, 61, 635-655.

Педагошки речник [Dictionary of Pedagogy] (1967). Београд: Завод за издавање уџбеника CPC.

Pedagoška encikolpedija [Encyclopedia of Pedagogy] (1989). Beograd: Zavod za uđžbenike i nastavna sredstva. 
Previšić, V. (2000). Slobodno vrijeme između pedagogijske teorije i odgojne prakse [Leisure time between pedagogical theory and educative practice]. Zagreb: Napredak, 141 (4), 403-410.

Ricijaš, N., Krajcer, M., \& Bouillet, D. (2010). Rizična ponašanja zagrebačkih srednjoškolaca - razlike s obzirom na spol [Risky behavior of high school students in Zagreb-gendered differences]. Odgojne znanosti. 12 (1), 45-63.

Rizvan, M. (2013). Povezanost privrženosti prijateljima i sklonosti rizičnim ponašanjima $i$ delikvenciji $u$ adolescenciji [The connection of closeness to friends with the affinity towards risky behavior and deliquence in adolescence]. Diplomski rad. Zagreb: Filozofski fakultet.

Rosić, V. (2005). Slobodno vrijeme - slobodne aktivnosti [Leisure time - leisure activities]. Rijeka: Biblioteka Educo.

Станојевић, Д. (2019). Савремени модели менталног здравља - од одсуства патологије до благостаға [Modern models of mental health - from the absence of pathology to well-being]. Косовска Митровица: Филозофски факултет Универзитет у Приштини са привременим седиштем у Косовској Митровици.

Stanojević, D., Radović, O., \& Jaredić, B. (2013). Korelacije između zadovoljstva porodicom, rizičnog ponašanja, pozicije u društvu i akademskog uspeha kod srednjoškolaca [Correlation between satisfaction with family, risky behavior, social status and academic achievement among the high school students]. Saopštenje na 19. naučnom skupu empirijska istraživanja u psihologiji. Beograd: Institut za psihologiju, Laboratorija za eksperimentalnu psihologiju, Filozofski fakultet, Univerzitet u Beogradu. Rezimei, 178-179.

Skaar, N. R. (2009). Development of the Adolescents' Exploratory and Risk Behaviour Rating Scale. (Unpublished Doctoral Dissertation). Faculty of the Graduate School of the University of Minnesota, USA.

Trnavac, N., \& Đorđević, J. (2010). Pedagogija [Pedagogy]. Beograd: Naučna KMD.

Ćurčić, V. (2005). Mentalno zdravlje mladih - rizik i šansa [Mental health of the young - risks and chances]. Beograd. Psihijatrija danas, 37(1), 87-107.

Fredricks, J. A., Alfeld-Liro, C. J., Hruda, L. Z., Eccles, J. S., \& Ryan, A. M. (2002). A qualitative exploration of adolescents' commitment to athletics and the arts. Journal of Adolescent Research, 17, 68-97.

Henderson, K. (2010). Leisure studies in the 21 st century: The sky is falling? Leisure Sciences, 32, 391-400.

Hafner, P. (1997). Društvene promene i društvene krize danas. [Changes in society and social crises today]. Teme, XX (3-4), 327-337.

Holt, M. (1998). Young People, Leisure and the Construction of Sexual Identities: A report on work in progress. UK: University of Birmingham.

Caldwell, L. L. (2008). Youth development through leisure: A global perspective. World Leisure Journal, 50 (1), 3-17.

Caldwell, L. L., \& Baldwin, C. K. (2005). A developmental approach to understanding constraints to adolescent leisure. In E. L. Jackson (Ed.), Constraints to leisure (pp. 75-88). State College, PA: Venture Publishing Inc.

Csikszentmihalyi, M., \& LeFevre, J. (1989). Optimal experience in work and leisure. Journal of Personality and Social Psychology, 56, 815-822.

Cohen-Gewerc, E.,\& Stebbins, R. A. (2007). The idea of leisure. In E. Cohen-Gewerc \& R. A. Stebbins (Eds.), The pivotal role of leisure education: Finding personal-fulfillment in this century (pp. 1-14). State College, PA: Venture.

Cooper, H., Valentine, J. C., Nye, B., \& Lindsay, J. J. (1999). Relationships between five after-school activities and academic achievement. Journal of Educational Psychology, 91, 369-378. 


\title{
STRUCTURED AND UNSTRUCTURED TIME AND RISKY BEHAVIOR OF ADOLESCENTS IN CONDITIONS OF SOCIAL CRISIS
}

\author{
Biljana Jaredić, Jelena Minić, Tatjana Radojević \\ University of Priština, Faculty of Philosophy, Kosovska Mitrovica, Serbia
}

\begin{abstract}
Summary
The importance of leisure time management and its influence on the growth and strengthening of personality, still does not cease to intrigue the scientific public. There is a disagreement in the literature regarding developmental opportunities and benefits connected with structured and unstructured youth activities during their leisure time. With this research we will discover how adolescents spend, i.e. structure free time (structured and unstructured, i.e. free time and leisure) in conditions of actual social crisis.

The main objective of this research is to determine how much adolescents prefer certain types of structured free time and unstructured time (leisure time), as well as their connection with risky behavior of adolescents in social crisis. The sample consists of a number of adolescents $(\mathrm{N}=287$ ), both male and female ( 116 or $40.4 \%$ of male and 171 or $59.6 \%$ of female respondents), ages 18 to 24 , with the average age being 20.44 years (AS = 20.44, SD $=2.75$ ) living in the Autonomous Province of Kosovo and Metohija. The Leisure and Leisure Assessment Questionnaire and the Basic Socio-demographic Characteristics Questionnaire and the Risk Behavior Rating Scale (RBRS) (Scaar, 2009) were used during this research. Data were processed by descriptive statistics, correlation and regression analysis and the T-test. The results obtained in this research showed that adolescents prefer the Internet as an unstructured activity, and they least prefer the theater as a structured activity. They spend more than 10 hours in these activities per week (such as the Internet, cafes, socializing with peers and walks). A negative correlation between age and structured and unstructured time was obtained, which indicates that adolescents have less free time (both free structured and leisure or unstructured time) as they grow up. Also, a negative correlation was obtained between academic success and risky behavior, which means that if adolescents achieve better results in academic careers, they have less propensity for risky behavior. Research showed that structured time is not significantly related to risky behavior, indicating that some other variables are inserted between structured leisure and risky behavior, which should be further examined in the continuation of this study. Also, unstructured time is significantly related to and a significant predictor of risky behavior for youth as a target. The results also indicate that boys are more prone to risky behavior than girls. Adolescent risk behavior can be predicted with $14 \%$ of variance (significant predictors are unstructured leisure time and gender of adolescents). Better understanding of leisure management can contribute to better life quality of individuals, community and to the immediate social environment. It is especially important to know the consequences of bad management of adolescent unstructured leisure time in the time of social crisis having in mind that changes and environmental conditions can intensify and change common forms of psychopathology or contribute to the emergence of new forms of psychopathology or other behavioral disorders.
\end{abstract}

